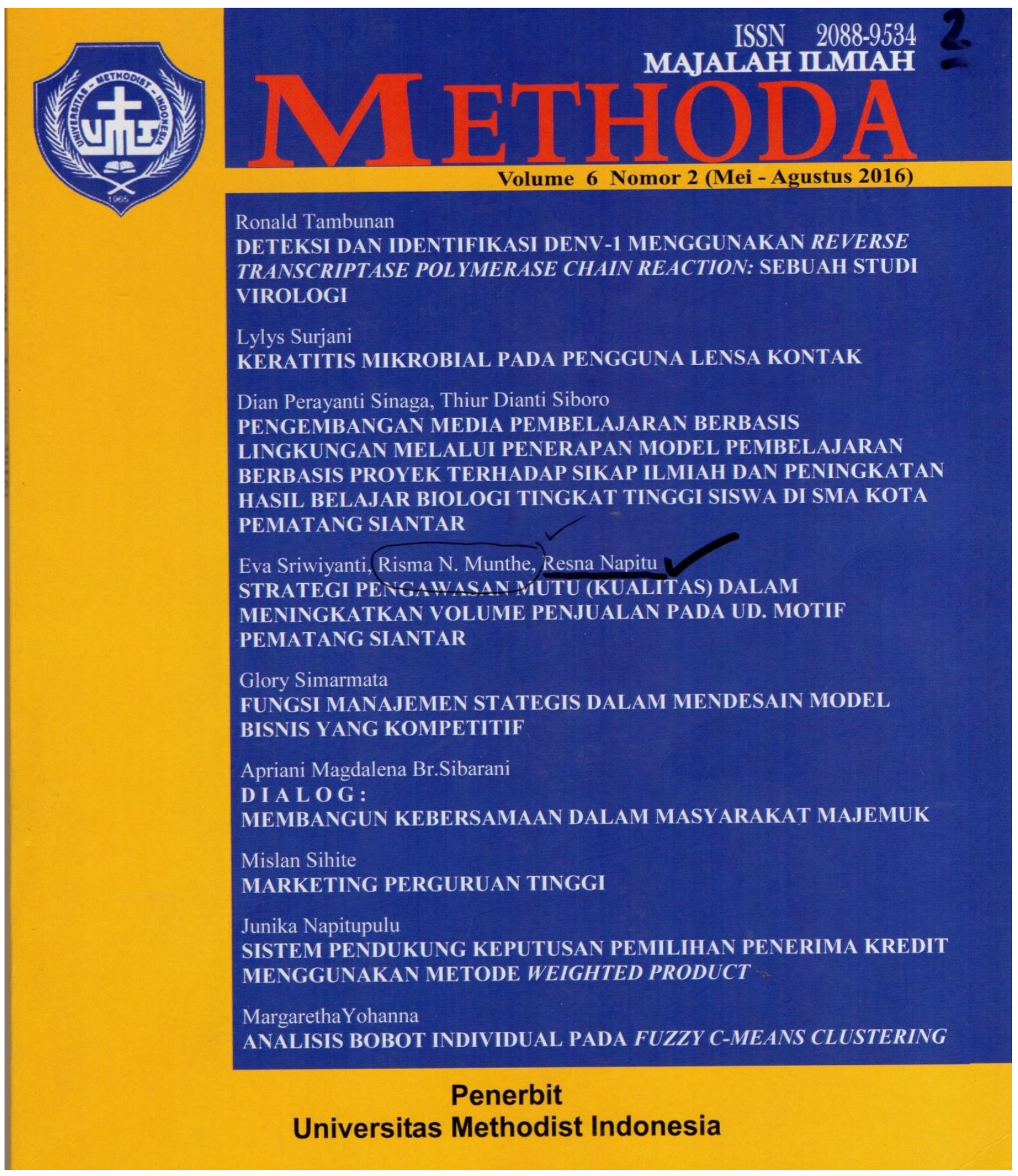




\section{ISSN $2088-9534$ \\ MAJALAH IIMIAH

Ronald Tambunan

DETEKSI DAN IDENTIFIKASI DENV-1 MENGGUNAKAN

REVERSE TRANSCRIPTASE POLYMERASE CHAIN REACTION: $\quad 1-12$ SEBUAH STUDI VIROLOGI

Lylys Surjani

KERATITIS MIKROBIAL PADA PENGGUNA LENSA KONTAK

Dian Perayanti Sinaga, Thiur Dianti Siboro

PENGEMBANGAN MEDIA PEMBELAJARAN BERBASIS

LINGKUNGAN MELALUI PENERAPAN MODEL

PEMBELAJARAN BERBASIS PROYEK TERHADAP SIKAP

ILMIAH DAN PENINGKATAN HASIL BELAJAR BIOLOGI

$27-33$

TINGKAT TINGGI SISWA DI SMA KOTA PEMATANG SIANTAR

Eva Sriwiyanti, Risma N. Munthe, Resna Napitu

STRATEGI PENGAWASAN MUTU (KUALITAS) DALAM

MENINGKATKAN VOLUME PENJUALAN PADA UD. MOTIF $34-46$

PEMATANG SIANTAR

Glory Simarmata

FUNGSI MANAJEMEN STATEGIS DALAM MENDESAIN MODEL BISNIS YANG KOMPETITIF

$47-55$

Apriani Magdalena Br.Sibarani

D I A L O G :

MEMBANGUN KEBERSAMAAN DALAM MASYARAKAT

$56-63$

MAJEMUK

Mislan Sihite

MARKETING PERGURUAN TINGGI

$64-78$

Junika Napitupulu

SISTEM PENDUKUNG KEPUTUSAN PEMILIHAN PENERIMA KREDIT MENGGUNAKAN METODE WEIGHTED PRODUCT

MargarethaYohanna

ANALISIS BOBOT INDIVIDUAL PADA FUZZY C-MEANS

CLUSTERING 


\title{
STRATEGI PENGAWASAN MUTU (KUALITAS) DALAM MENINGKATKAN VOLUME PENJUALN PADA UD.MOTIF \\ PEMATANGSIANTAR
}

\author{
Eva Sriwiyanti, Risma N.Munthe,Resna Napitu \\ Dosen Program Studi Akuntansi Universitas Simalungun \\ e-mail: eva.sriwiyanti@yahoo.co.id
}

\begin{abstract}
The ppurpose of this research is to determine whether the implementation of the quality of supervising strategys (quality) increasing the selling volume by UD.MOTIF Pematangsiantar. It is a field research conducted through surveys and interviews to the leaders and employees UD.MOTIF

The outcomes of this research is to help the entrepreneurs/craftsmen to create a monitoring quality method of products to be better, to help the entrepreneurs/craftsmen to manage the quality of product in accordance with the consumers'desire and help to distribute their products.

The conclusion of research, the quality supervising method conducted is already good by UD.MOTIF where the principal supervised the workers directly on the field. To manage the quality of products according to consumer desire UD.MOTIF leaders need to have a good standard of human resources, trained and experienced in the art of seni Ukir Jepara (Jepara sculpture) and sufficient fund to run the business and support by the avaibility of raw materials. UD.MOTIF product marketing has been running well by creating a corporate blog on the internet, radio ads, brochures, infonmation by word of mouth and following the exhibitions held in Pematangsiantar.
\end{abstract}

Keywords: Quality supervising, selling volume.

\section{Pendahuluan}

Meubel merupakan salahsatu produk industry kerajinan tangan yang mempunyai peran cukup penting dalam memenuhi kebutuhan masyarakat. Industry meubel merupakan salah satu bentuk pemberdayaan usaha mikro kecil menengah (UMKM) yang diharapkan dapat menyerap tenaga kerja sekaligus meningkatkan pendapatan pelakunya. 
Kerajinan maubel ukiran Jepara meupakan salah satu warisan budaya yang harus dilestarikan. Hasil kerajinan tangan ini bernilai tinggi karena dilakukan oleh orang-orang yang terampil dan terlatih serta mempunyai jiwa seni yang tinggi. Dilihat dari jumlah pengrajin /pengusaha khususnya di Kota Pematangsiantar jumlahnya masihh sangat terbatas. Di Pematangsiantar perusahaan meubel Jepara yang cukup dikenal oleh masyarakat ada 4 (empat), salh satunya adalah UD.Motif. produk yang dihasilkan oleh UD.Motif adalah moubel dan souvenir yagn dipasarkan didalam dan diluar kota Pematangsiantar. Dalam menghasilkan produk UD.Motif memerlukan bahan baku yagn cukup banyak yang didatangkan dari luar kota ,sehingga membutuhkan biaya produksi yang sangat tinggi. Dengan tingginya biaya produksi maka harga jual juga semakin tinggi. Tinggi nya harga jual tersebut diharapkan sebanding dengan kualitas yang diberikan, sehingga produk yang dihasilkan dapat memenuhi kepuasan konsumen.

Dalam memenuhu kebutuhan konsumen UD.Motif menghadapi maslah sulitnya memperoleh bahan baku (kayu) sesuai dengan pesan konsumen. Selanjutnya sebagaimana diketahui bahwa produksi adalah merupakan salahsatu kegiatan yang paling penting dalam suatu perusahaan . Suatu proses produksi yang didukung oleh system produksi yang baik juga bukan meruupakan jaminan akan kelancaran proses produksi, artinya penyimpanganpenyimpangan tetap dapat terjadi. untuk itu diperlukan suatu pengawasan mutu mulai dari masuknya nahan sampai dengan produk siap untuk dijual.

Berdasarkan latar belakang tersebut maka peneliti peneliti membuat rumusan masalah sejauh mana peran strategi pengawasan mutu (kualitas) yang dilakukan oleh UD.Motif Pematangsiantar dalam meningkatkatkan volume penjualan?

Adapun tujuan dari penellitian ini adalah untuk mengetahui peran strategi pengawasan mutu (kualitas) yang dilakukan oleh UD.Motif Pematangsiantar dalam meningkatkan volume penjualan. 


\section{TINJAUAN PUSTAKA}

\section{Pengertian pengawasan, Mutu dan Pengawasan Mutu}

Menurut Kedarman (2001), “pengawasan adalah suatu upaya yang sistematik untuk menetapkan kinerja satandar pada perencanaan untuk merancang system umpan balik informasi, untuk membandingkan kinerja actual dengan standar yang telah ditentukan, untuk menetapkan apakah telah terjadi suatu penyimpangan tersebut, serta untuk mengambil tindakan perbaikan yang diperlukan untuk menjamin bahwa semua sumber daya perusahaan “. Menurut Winardi (2000), "pengawasan ialah semua aktivitas yang dilaksanakan oleh pihak manajer dalam upaya memastikan bahwa hasil actual sesuai dengan hasil yang direncanakan".

Pengawasan pada dasarnya diarahkan sepenuhnya untuk menghindari adanya kemungkinan penyelewengan atau penyimpangan atas tujuan yang akan dicapai, melalui pengawasan diharapkan dapat membantu melaksanakan kebijakan yang twlah ditetapkan untuk mencapai tujuan yang telah direncanakan secara efektif dan efisien,. Bahkan, melalui pengawsan tercipta suatu aktivitas yang berkaitan erat dengan penentuan atau evaluasi mengenai sejauh mana pelaksanaan kerja sudah dilaksanakan. Pengawasan juga bias mendeteksi Sejauh mana kebijakan pimpinan dijalankan dan sampai sejauh mana penyimpangan yang terjadi dalam pelaksanaan kerja tersebut.

Konsep pengawasan demikian sebaenarnya menunjukkan pengawasan merupakan bagian dari fungsi manajemen, dimana pengawasan didanggap sebagai bentuk pemeriksaan atau pengontrolan dari pihak yang lebih atas kepada pihak yang dibawahnya. Dalam ilmu manajemen, pengawasan ditempatkan sebagai tahapan terakhir dari fungsi manajemen . dari segi manajerial, pengawasan mengandung makna pula sebagai pengamatan atas pelaksanaan seluruh kegiatan unit orrganisasi yang diperiksa untuk menjamin agar seluruh pekerjaan yang sedang dilaksanakan sesuai dengan rencana dan peraturan.

\section{Mutu}

Mutu merupakan hal yang penting dalam membangun dan mengelola fungsi produksi. Mutu akan mempengaruhi seluruh aktivitas perusahaan dari pemasok sampai konsumen dan dari manajemen produk sampai aspek pemeliharaan peralatan. Tujuan akhir adalah menjadi perusahaan yang efektif dan efisien serta mempunyai keunggulan 
kompetitif terhadap produk yang dihasilkan. Mutu memiliki banyak kriteria dan sangat tergantung pada konteks.

Menurut Garvin dan Davis dalam Nasution (2015) mutu/kualitas merupakan suatu kondisi dinamis yang berhubungan dengan produk, jasa, manusia, proses dan lingkungan yang memenuhi dan melebihi harapan. Kualitas bukan hanya menekankan pada aaspek hasil akhir, yaitu produk dan jasa tetapi juga menyangkut kualitas manusia, kualitas proses, dankualitas lingkungan agar dapat memenuhi atau melebihi harapan konsumen.

Menurut Crosby dalam Nasution (2015) kualitas adalah conformance to requirement, yaitu sesuai dengan yang diisyaratkan atau distandarkan. Ini berarti suatu produk dianggap memiliki kualitas apabila sesuai dengan standar kualitas yang telah ditentukan. Standar kualitas tersebut meliputi bahan baku, proses produksi dan produk akhir. Sedangkan pada perusahaan manufaktur istilah mutu adalah suatu proses produksi yang berkaitan dengan kegiatan merancang dan membuat produk untk memenuhi kebutuhan konsumen arau pelanggan.

Menurut Roger dalam Nasution (2014) mutu merupakan kecocokan penggunaan. Ini berarti produk yang dihasilkan untuk memenuhi kebutuhan konsumen dan produk tersebut cocok dengan penggunaan akan kebutuhan konsumen. Kecocokan konsumen dikaitkan dengan nilai yang diterima dan diberikan kepada konsumen.

Secacra singkat mutu dapat diartikan sebagai suatu kecocokan penggunaan. Seperti yang diuraikan oleh Juran Nasution (2015), kecocokan dalam penggunaan ini didasarkan atas lima ciri mutu, yaitu:

1. Teknologi (kekuatan produk, desain produk, dan tingkat kesulitan produk yang dihasilkan)

2. Psikologis (citarasa dan tata warna yang sesuai dengan keinginan konsumen)

3. Orientasi wwaktu (kehandalan dan kemampuan peralatan)

4. Kontraktual ( adanya jaminan apabila produk yang diterima oleh konsumen mengalami kerusakan)

5. Etika (kesopan santunan pelanggan dan kejujuran)

Perusahaan harus menetapkaknk standarisasi dalam hal mutu dan mengaplikasikannya serta berusaha untuk mencpai spesifikasi yang direncanakan sambil terus-menerus melaksanakan penyempurnaan terhadap produk yang siihasilakan.

Menurut Assauri (2011) dalam sebuah perusahaan manufaktur istilah mutu diartikan sebagai faktor-faktor yang terdapat dalam suatu barang atau hasil yang menyebabkan barang atau hasil tersebut sesuai degan tujan untuk apa barang atau hasil itu dimaksudkan atau 
dibutuhkan. Apabila dalam hal ini produsen telah salah menentukan atau memutuskan ketepatan tujuan untuk apa hasil/barang tersebut dimaksudkan, maka pembeli atau konsumen yang telah membeli hasil/barang itu tidak akan kembali membelinya.

\section{Pengawasan mutu}

Menurut Puspitasari (2004), "Pengawasan mutu adalah kegiata yang dilakukan untuk menjamin bahwa proses yang terjadi akan menghasilakan produk sesuai dengan tujuan yang diinginkan. Kegiatan pengawasan mutu adalah mengevaluasi kinerja nyata proses dan membandingkan inerja nyata proses dengan tujuan. Hal tersebut meliputi semua kegiatan dalam rangka pengawasan rutin mulai dari bahan baku, proses produksi hingga produk akhir." Pengawasan mutu bertujuan untuk mencapai sasaran dikembangkannya peraturan dibidang proses sehingga produk yang dihasilkan aman dan sesuai dengan keinginan masyarakat dan konsumen. Pengendalian mutu merupakan alat bagi manajemen untuk memperbaiki mutu produk jika diperlukan, mempertahankan mutu produk yang sudah tinggi dan mengurangi jumlah produk yang rusak. Tujuan jangka panjang perusahaan yaitu mempertahankan pasar yang telah ada atau menambah pasar perusahaan.

Kebutuhan akan pengawasan mutu timbul setelah revolusi industry oleh kaena proses produksi dikerjakan dengan mesin, maka menimbulkan dua personal yaitu:

a. Penggunaan mesin mulai menggantikan atau mengurangi kebutuhan dan penggunaan tenaga-tenaga atau tukang-tukang yang mempunyai keahlian yang tinggi.

b. Produksi barang-barang secara besar besaran memerlukan saling pertukaran, sehingga selanjutnya dibutuhkan keseragaman dari komponen-komponen uuntuk memudahkan mengesampingkannya.

Adapun yang dimaksud dengan pengawasan mutu adalah kegiatan untuk memastikan apakah kebijaksanaan dalam hal baku (standar) dapat tercermin dalam hasil akhir. Dengan perkataan lain pengaawasan mutu merupakan usaha untuk mempertahankan mutu dari barang yang dihasilkan agar sesuai dengan spesifikasi produk yang telah ditetapkan berdasarkan kebijaksanaan pimpinan perusahaan.

Dalam pengawasan mutu ini semua prestasi barang di check menurut standar dan semua penyimpangan -penyimpangan standar dicatat serta dianalisa dan semua penemuanpenemuan dalam hal ini dipergunakan sebagai umpan balik (feed back) untuk para pelaksana sehingga merekadapat melakukan tindakan-tindakan perbaikan untuk produksi pada masa yang akan dating.

\section{Maksud dan Tujuan Pengawasan Mutu}


Seperti telah dilakukan bahwa maksud dari pengawasan mutu adalah agar spesifikasi produk yang telah ditetapkan sebagai standar dapat tercermin dalam hasil akhir. Secara terperinci dapatlah dikatakan bahwa tujuan dari pengawasan mutu adalah:

a. Agar barang hasil produksi dapat mencapai standar mutu yang telah ditetapkan

b. Mengusahakan agar biaya inspeksi dapat menjadi sekecil mungkin

c. Mengusahakan aar biaya produksi dapat menjadi serendah-rendahnya

\section{Sistem Pengawasan}

Menurut Siagian (2004), system pengawasan pada dasarnya dapat digolongkan atas 2 bagian yaitu:

a. Pengawasan langsung

Adalah pengawasan yang dilakukan secara pribadi oleh pimpinan terhadap kegiatan yang sedang dijalakan. Pengawasan ini dapat berbentuk inspeksi langsung, on the spot observation dan on the sport report.

b. Pengawasan tidak langsung

Merupakan suatu pengawasan yang dilakukan secara jarak jauh. Pimpinan melakukan pengawasan melalui laporan yang disampaikan oleh bawahan. Laporan dapat berbentuk tulisan maupun dalam bentuk lisan. Kelemahan dari sistem pengawasan tidak langsung ini adalh seering bawahannya hanya menyampaikan hal-hal yang bersifat positif saja.

\section{Faktor- faktor yang mempengaruhi Mutu}

Mutu dipengaruhi oleh faktor yang akan menentukan bahwa suatu barang dapat dipenuhi tujuannya. Oleh karana itu mutu merupakan tingkatan pemasaran sutu barang Assauri (2011), tingkat mutu tersebut di tentukan oleh beberapa faktor antara lain:

a. Fungdi suatu barang

Suatu barang yang dihasilkan hendaknya memperhatikan fungsi untuk apa barang tersebut digunakan atau dimaksud sehingga barang-barang yang dihasilkan harus dapat benar-benar memenuhi fungsi tersebut.

b. Wujud luar

Salah satu faktor yang penting dan sering dipergunakan oleh konsumen dalam melihat suatu barang pertama kalinya untuk menentukan suatu barang tersebut adalah wujud luar barang itu.

c. Biaya barang 
Biaya dan harga barang akan dapat menentukan mutu barang tersebut. Hal ini terlihat dari barang-barang yang mempunyai biaya harga yang mahal dapat menunjukkan bahwa mutu barang tersebut relatif lebih baik.

d. Biaya mutu (quality costs)

Seperti kita ketahui bahwa mutu suatu barang merupakan kesesuaian maksud tujuan (fitness for purpose) dari barang tersebut. Hampir setiap produsen ingin berusaha memeperbaiki mutu dari barang yang dihasilkan.

\section{PerumusanKebijaksanaan Dalam Mutu}

Untuk menghasilkan suatu produk yang bermutu baik maka dipererlkan suatu kebijaksanaan atau keputusan yang tepat. Biasanya mutu suatu produk ditentukan oleh para teknisi yang terlibat pada proses produksi walaupun pada dasarnya teknisi yang terlibat langsung dapada setiap tahap dan siklus darilam proses produks juga kita perlu memperhatikan beberapa aspek atau faktor-faktor lainnya yaitu:

a. Proses produksi

Untuk mendapatkan produk yang bermutu sesuai dengan yang ditetapkan maka perlu diperhatikan siklus proses pembuatan diamna untuk mendapatkan kualitas yang baik dibutuhkan waktu yang lebih lama.

b. Aspek penjualan

Faktor kualitas yang ingin dicapai serta erat hubungannya dengan kegiatan penjualan. Apabila mutu dari produk yang dihasilkan terlalu rendah, maka hal itu dapat menyebabkan berkurangnya penjualan.

c. Perubahan permintaan konsumen

Konsumen sering menginginkan terdapatnya perubahan dadri barang yang dipakai, perubahan yang seperti ini disebut mode. Perubahan ini perlu diperhatikan produsen sehingga ia dapat mengetahui dan mengikuti selera konsumen.

d. Peranan inspeksi

Untuk dapat menghasilkan produk agar sesuai menurut standar yang telah ditetapkan, maka peraan inspeksi sangat penting. Dalam hal ini perlu diingatkan bahwa inspeksi hanya dapat mengawasi atau menjaga mutu agar sesuai dengan apa yang telah ditetapkan dalam standar.

\section{Teknik dan Alat-alat Pengawasan mutu}


Pada setiap tahap dan siklus dari pemikiran tentang hasil sampai pada perencanaan pengumpulan bahan-bahan pengolahan, pengepakan penjualan dan lamanya suatu hasil dapat dipergunakan maka perlu dijalankan pengawasan terhadaap mutu yang dalam hal ini dapat dilakukan dengan tiga cara yaitu inspeksi, pemberian keterangan dan penyelidikan

\section{Ruang Lingkup Pengawasan Mutu}

Kegiatan pengawasan mutu sangat luas, karena semua pengaruh terhadap mutu harus diperhatikan. Secara garis besar pengawasan mutu dapat dibedakan dalam tiga yaitu:

a. Pengawasan Pendahuluan atau sering disebut steering controls Pengawasan ini dirancang untuk mengaktifkan masalah- masalah atau penyimpangan-penyimpangan dari standar atau tujuan dan memungkinkan koreksi dibuat sebelum suati kegiatan tertenu selesai.

b. Pengawasan yang dilakukan bersamaan dengan pelaksanaan kegiatan (cocurent con trol)

Tipe pengawasan ini merupakan proses dimana aspek tertentu dari suatu prosedur harus disetujui dulu atau syarat tertentu harus dipenuhi dulu sebelum kegiatankegiatan biasa dilanjutkan atau menjadi semacam peralatan 'double-deck' yang habis menjamin ketepatan pelaksanaan suatu kegiatan.

c. Pengawasan umpan balik

Ini berguna untuk mengukur hasil-hasil dari suatu kegiatan yagn telah diselesaikan. Sebab-sebab penyimpangan dari rencana atau standar ditentukan dan penemuanpenemuan diserapkan untuk kegiatan serupa dimasa yang akan datang. M.Manullang (2000) mengatakan bahwa cara menjalankan pengawasan produksi meliputi empat aktivitas yaitu:

a. Routing

Adalah fungdi yang menentukan dan mengatur urutan kegiatan pengerjaan yang logis, sistematis dan ekonomis

b. Scheduling

Merupakan pengkoordinasi tentang waktu dalam kegiatan produksi sehingga dapat diadakan pengalokasian bahan-bahan pembantu, serta perlengkapan kepada fasilitas-fasilitas pada bagian-bagian pengolahan dalam pabrik dalam waktu yang telah ditentukan.

c. Dispatching 
meliputi pelaksanaan dadri semua rencana dan peraturan dalam bidang routing dan scheduling, sebagian besar kegiatan dalam dispatching ini terdiri dari penyampaian pemerintah kepada bagian pengolahan yang dilakukan sesuai dengan dan urutan pekerjaan yang telah ditentukan. Adapun tugas dari dispatching adalah sebagai berikut:

1. Membuat perintah penyediaan lengkap dengan kartu tugas dan daftar Hkeperluan barang-barang

2. Mneliti tersedianya bahan -bahan sebelum perintah order dibuat sebenarnya dispatching memberikan keterangan mengenai :

a. Pergerakan bahan-bahan yang baru dilakukan ditempat yang telah ditentukan

b. Pengerjaan mesin yang harus dilakukan untuk setiap kegiatan operasi

c. Pencatatan waktu kapan dimulai melaksanakan kegiatan operasi

d. Penyelenggaraan pekerjaan sesuai dengan routing dan scheduling.

d.FollowUp ( pemeriksaan )

merupakan fungsi penelitian dan pengecekan terhadap semua aspek yang dipengaruhi kelancaran kegiatan pengerjaan/produk. Follow up ini mencakup usaha untuk mendapatkan bahan baku yagn tidak tersedia tetapi dibutuhkan.

Mencari supplier mana yang paling baik untuk mendapatkan bahan-bahan baku tersebut, juga meneliti mesin-mesin dan peralatan-peralatan yang diperlukan serta mengenai penjualan apakah hasilnya baik juga mengenai cara-cara dan syarat-syarat.

\section{METODOLOGI PENELITIAN}

Penelitian ini merupakan penelitian dekriptif kualitatif yang datanya berupa hasil wawancara dan survei kepada pimpinan, karyawan, blog internet, brosur dan foto-foto hasil produksi UD.MOTIF.

\section{HASIL DAN PEMBAHASAN}

Hasil penelitian berdasarkan target iuran adalah sebagai berikut:

a. Setelah dilakukan wawancara dan observasi langsung ke UD.MOTIF, maka diperoleh data tentang pengawasan yang dilakukan oleh pengusaha yaitu pengusaha yaitu pengawasan secara langsung dalam mengelola kualitas produk. Proses produksi pada UD.MOTIF menggunakan teknologi sederhana secara manual untuk pekerjaan kecil dan rinci. Pada pekerjaan yang lebih berat sudah menggunakan teknologi semi modern, yaitu dalam proses pemotongan, penyerutan dan penghalusan untuk bidang-bidang yang lebih 
luas. Proses pembuatan furniture kayu merupakan gabungan proses makanik (pemotongan, pengeboran dan pemolaan kayu) dan pengerjaan seni ( dan pembentukan akhir sesuai contoh model). Furniture kayu yang dihasilkan merupakan produk yang mempunyai kandungan seni menurut model dan fungsi produk yang dikehendaki.

Proses pengawasan kualitas yang dilakukan oleh UD.MOTIF melalui tahapan produksi antara lain:

1. Bahan Mentah

Ketika bahan mentah yang dipesan sampai di bengkel kerja pihak pimpinan mengawasi secara langsung yakni jenis, ukuran dan kualitas kayu secara langsung, apabila kayu yang sudah dipesan tidak sesuai dengan pesanan maka akan dikdembalikan kepada pemasok akan tetapi sejauh ini belum pernah terjadi kesalahan dalam penerimaan pesanan bahan mentah. Untuk menjaga kualitas kayu tetap awet maka diberikan obat pengawet sesuai dengan standard yang dibutuhkan.

2. Pengovenan bahan mentah

Setelah bahan mentah dinyatakan sesuai dengan kualitas yang ditetapkan, maka bahan mentah tersebut dilaanjutkan ke proses pengovenan yang bertujuan untuk mengurangi kadar air yagn terkandung didalam kayu. Standard kadar air yang ditentukan oleh UD.MOTIF sebesar 10\% agar kualitas produk yang dihasilkan kuat dan awet.

3. Pemotongan kayu

Setelah proses pengovenan selesai maka akan dilakukan pemotongan kayu sesuai dengan kebutuhan produk yang akan dihasilkan. Proses pemotongan inidilakukan ditempat lain disebabkan UD.MOTIF bellum memiliki mesin pemotong kayu. Namun demikian pimpinan tetap melakukan pengawasan secara langsung ke tempat pemotongan kayu untuk memperkecil tingkat kesalahan dalam pemotongan kayu.

4. Pembuatan mal bengkok

Proses pembuatan mal bengkok ini menggunakan mesin spindel yang tujuannya adalah untuk membuat komponen kursi yang memerlukan komponen dengan bentuk membengkok atau melengkung.

5. Membuat purus (berbentuk lanangan)

Komponen yang telah dioven kemudian dilanjutkan pada proses pembuatan purus. Purus disini ada 2 macam, yaitu lanangan dan wedokan. Untuk pembuatan purus lanangan ini menggunakan mesin tenon.. purus lanangan ini fungsinya adalah semacam untuk pengunci antara komponen satu dengan komponen lain. 
6. Membuat dudukan

Komponenlain yang telah dioven selanjutnya juga ada yang diproses untuk menjadi dudukan. Untuk proses membuat dudukan ini menggunakan mesin laminating atau juga biasa disebut tanggem.

7. Membuat Purus (berbentuk wedokan)

Hal yang sama juga dilakukan dengan komponen yang telah dioven unutk pembuatan purus. Bila tadi untuk purus berbentuk lanangan,namun kali ini untuk purus berbentuk wedokan. Proses pembuatannya menggunakan mesin morstis (mesin bobok)

8. Pengamplasan

Setelah proses diatas dikerjakan dengan baik, maka selanjutnya produk diamplas untuk menghaluskan permukaan permukaan produk agar lebih rata dan halus sehingga terlihat lebih rapi. Pengamplasan dilakukan dengan menggunakan mesin amplas, selama proses pengamplasan pimpinan melakukan pdengawasan dengan tujuan jika sitemukan produ yang kurang rapi atau masih kasar maka pekerja disuruh untuk segera memperbaikinya.

9. Perakitan

Setelah semua dikerjakan maka proses selanjutnya adalah perakitan, dalam proses perakitan ini dilakukan sesuai dengan gambar yang telah didesain sesuai dengan permintaan konsumen, apabila terjadi kesalahan maka pimpinan mengarahkan dan memastikan sambungan antara komponen yang satu dengan yang lain harus rapat dan tetap rapi.

10. Shanding ( menutup pori-pori kayu)

Pengamplasan kedua untuk lebih menghaluskan komponen-komponen kayu. Dalam proses sanding bertujuan untuk menghaluskan kembali bekas sambungan agar terlihat rata dan rapi. Proses shanding ini dilakukan dengan manual maupun dengan mesin pengamplas.

11. Pengobatan

Proses pengobatan untuk produksi kayu di bawah ini dan unfinis. Untuk proses finish menggunakan $\mathrm{HCL}$ dan $\mathrm{H} 2 \mathrm{O} 2$ dengan perbandingan 1 hcl dan dan $5 \mathrm{H} 2$ dengan perbandingan $1 \mathrm{Hcl}$ dan $5 \mathrm{H} 2 \mathrm{O} 2$. Untuk tukarannya bisa menggunakn gayung atau ukuran liter tergantung kebutuhan. Proses pengobatan ini dilakukan 3-5 kali untuk setiap kursi tergantung alur minyak finishing malamin pada tiap kursi. 


\section{Woodfiler}

Proses ini adalah proses pendempulan atau meratakan permukaan kayu yang kurang rata agar tampak lebih halus dan rapi.

13. Spray shanding seller

Setelah habis didempul lalu produk disemprot dengan cat dasar sebelum diberi warna. Dalam proses ini pengawasan yang dilakukan oleh pimpinan dengan cara memastikan cat dasar sesuai dengan permintaan konsumen.

14. Shanding warna

Proses ini adalah pemberian warna pada kursi. Pada proses pemberian warna sesuai dengan pesanan pembeli. Rata-rata setiap buyer yang berbeda memiliki selera warna yang berbeda. Dalam proses ini pimpinan mengawasi apakah pemberian warna sudah merata sehingga tidak terlhat perbedaan warna pada setiap produk.

\section{Check QC Buyer}

Setelah seluruh tahapan pembuatan produk selesai maka langkah selanjutnya pimpinan menginformasikan kepada pembeli untuk meninjau atau melihat kualitas pesanannya, apakah telah sesuai dengan permintaan. Jika tidak ada keluhan maka produk dapat dilanjutkan kepada proses packing untuk selanjutnya di kirim.

16. Packing

Dalam proses packing pimppinan memastikan bahwa seluruh produk dilapisi dengan kardus sehingga jika terjadi gesekan tidak akan merusak cat dan produk secara keseluruhan.

\section{Kontainer}

Prosses kountainer adalah proses dimana produk-produk kursi yang telah di packing dimasukkan kedalam kontainer tersebut siap untuk dikirim kepada pemesan.

b. Membantu para penguasaha/ pengrajin mengelola kualitas sesuai dengan keinginan konsumen maka perlu memiliki tenaga kerja yagn ahli/ memahami dan berpengalaman dalam seni mengukir motif Jepara serta dapat dipercaya sehingga jika sewaktu-waktu pimpinan tidak berada ditempat maka proses produksdi tetap berjalan dengan baik sesuai dengan standard tanpa harus diawasi secara langsung oleh pimpinan.

Karyawan yang telah dihunjuk perlu diberikan pelatihan khusus untuk menguasai setiap tahapan dalam proses produksi. Selain tenaga kerja yang ahli juga dibutuhkan fasilitas/peralatan, mesin-mesin yang canggih dan ruang kerja yang lebih nyaman (memenuhi standard kualitas) dalam proses produksi oleh karena itu diperlukan modal 
kerja yang cukup. Sampai saat ini pemilik UD.MOTIF masih kekurangan modal untuk menjalankan usahanya, mnamun demikian pemilik UD.MOTIF sudah pernah mengajukan permohonan pinjaman modal usaha ke lembaga perbankan tertentu akan tetapi proses terebut terhambat karena prosedur yang yang dirasakan cukup berbelitbelit, sehingga pemilik tidak tertarik lagi untuk melanjutkan.

c. Membantu para pengusaha / pengrajin memasarkan produk yang dihasilkan Dalam memasarkan produk UD.MOTIF telah melakukan promosi melalui blog, perusahaan di interneet, iklan diradio, brosur, informasi dari mulut kemulut dan mengikuti pameran-pameran yang dilaksanakan di Kota Pematangsiantar. Dengan promosi yang selama ini sudah dilakukan produk UD.MOTIF sudah sangat dikenal oleh masyarakat Kota Pematangsiantar bahkan sampai keluar daerah.

\section{KESIMPULAN}

Kesimpulan dari hasil penelitian ini adalah:

a. Strategi pengawasan yang dilakukan oleh UD.MOTIF adalah pengawasan langsung dimana pimpinan turun langsung kelapangan mengawasi para pekerjanya bahkan turut serta mangambil bagian dalam menyelesaikan pekerjaan yang terlihat belum sempurna.

b. Dalam mengelola kualitas produk sesuai dengan keinginan konsumen pimpinan UD.MOTIF menghadapi kendala dlam hal ketersediaan bahan baku, minimnya SDM yang ahli, terlatih dan berpengalaman di bidang seni ukir Jepara serta kurangnya modal untuk menjalankan usaha.

c. Pemasaran produk UD.MOTIF sudah berjalan dengan baik yaitu melalui pembuatan blog perusahaan di internet, iklan radio, brosur, informasi dari mulut kemulut dan mengikuti pameran-pameran yang dilaksanakan di Kota Pematangsiantar.

\section{DAFTAR PUSTAKA}

Haizer jay dan Render Barry,2009. Mnajemen Operasi Buku I, Jakarta :Salemba Empat Komarudin,1994.,Manajemen Berdasarkan Sasaran,Jakarta:Bumi Aksara.

Kadarman dan Udaya Jusuf,2001. Pengantar Ilmu Manajemen. Jakarta: PT. Prenhallindo.

Manullang M., 2003, Pengantar Ekonomi Perusahaan. Yogyakarta:Liberty

Nasution M.Nur,2015. Manajemen Mutu Terpadu (TQM), Jakarta: Ghalia Indonesia

Siagian,Sondang P.2004, Filsafat Administrasi, (Edisi Revisi), Jakarta: Bumi Aksara.

Assauri Sofjan,2011, Manajemen Produksi dan Operasi, Jakarta: Lembaga Penerbit F.E.U.I 
Puspitasari,D.2004. Perbaikan dan Evaluasi Penerapan Sistem Manajemen Mutu Pada Industri Pengolahan Tahu. Institut Pertanian Bogor.

Winardi,2000, Manajer dan Manajemen. Bandung:Citra Aditya Bakti.

Sukanto dan Indriyo, 2008. Manajemen Poduksi, Edisi 4, Yogyakarta:BPFE. 